Sains Malaysiana 50(10)(2021): 2877-2884

http://doi.org/10.17576/jsm-2021-5010-03

\title{
Social Behaviour and Circadian Variations in Different Activities of Captive Hog Deer (Axis porcinus)
}

(Tingkah Laku Sosial dan Variasi Sirkadian dalam Aktiviti Berbeza Rusa Babi Peliharaan (Axis porcinus))

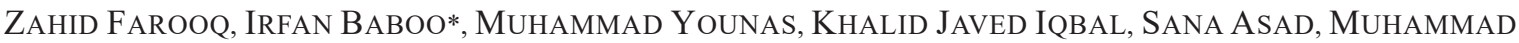 \\ Shahbaz, Muhammad Mazhar Munir, Muhammad Saleem Khan \& Muhammad Wajid
}

\begin{abstract}
Management practices/strategies to re-modulate the wild behaviour of animal species could increase their number in natural areas. The captive herd of hog deer showed slight changes from wild behaviour due to captive stress with no alteration in wild behaviour pattern except captive stress. Adult males (6), adult females (6) and fawns (6) were selected and observed round the clock for thirty days across season after one-hour interval on each activity. All subjects in hotter part of the day spent more time in sitting and rest. While, few hours of night in sleeping, resting and rumination. Fawn spent more time in sitting, resting, and hiding compared to adults. During wandering, they also spent some time in standing. It was noticed that all hog deer in herd not slept together but few of them remain active. Only male fighting was observed and maximum was noticed in August and September during breeding season. Hog deer were mainly crepuscular in feeding with irregular short intakes, and grazing on grasses present in enclosure. This study provides guideline to rehabilitate wild hog deer for better breeding management, conservation and raising practices.
\end{abstract}

Keywords: Captivity; circadian variation; hog deer; Pakistan; social behaviour

\section{ABSTRAK}

Amalan/strategi pengurusan untuk memodulasi semula tingkah laku liar spesies haiwan dapat meningkatkan jumlahnya di kawasan semula jadi. Kawanan rusa babi yang diternak menunjukkan sedikit perubahan daripada tingkah laku liar kerana tekanan tahanan tanpa perubahan pada corak tingkah laku liar kecuali tekanan tahanan. Jantan dewasa (6), betina dewasa (6) dan anak rusa (6) dipilih dan diperhatikan sepanjang masa selama tiga puluh hari sepanjang musim selang satu jam untuk setiap aktiviti. Semua subjek menghabiskan lebih banyak masa duduk dan berehat pada waktu panas. Sementara beberapa jam pada malam hari untuk tidur, rehat dan ruminasi. Anak rusa menghabiskan lebih banyak masa duduk, berehat dan bersembunyi berbanding orang dewasa. Semasa merayau, mereka juga meluangkan masa untuk berdiri. Telah diperhatikan bahawa semua rusa babi dalam kawanan tidak tidur pada masa yang sama dengan sebilangan kecil daripada mereka tetap aktif. Hanya rusa jantan bergaduh dan kebanyakannya diperhatikan berlaku pada bulan Ogos dan September semasa musim pembiakbakaan. Rusa babi kebanyakannya krepuskul daripada segi pengambilan pemakanan dengan masa makan pendek yang tidak teratur dan merumput rumput yang terdapat di kawasan sekitar. Kajian ini memberikan garis panduan untuk memulihkan rusa babi liar untuk pengurusan pembiakbakaan, pemuliharaan dan amalan pemeliharaan yang lebih baik.

Kata kunci: Kelakuan sosial; Pakistan; peliharaan; rusa babi; variasi sirkadian

\section{INTRODUCTION}

Hog deer (Axis porcinus) is regarded as threatened species in Pakistan, extinct from many places with gradual decline at other places (Azam et al. 2002). Wildlife enthusiasts has feeling that hog deer population is fast declining in Pakistan but no reliable data is available to support this notion and the status of hog deer was declared as endangered species (IUCN 2020). Realizing a fast decline of the species, Punjab Wildlife Department developed a breeding stock of hog deer in Changa Manga Wildlife reserve so that the genome of species is preserved to avoid catastrophic extinction of wild species. 
Each species of animal has its own inherent behaviour suiting to its body size and structure, and metabolic requirements, which is evolved through a long period of evolution making it fit to extract optimal benefits from its habitat (Williams 2008). The broad behavioural patterns are adjusted to varying degrees to ensure its survival under different conditions of habitat at different geographic areas and parts of the year. Captive or semi-captive conditions force individuals of a species to live under some level of advantage of ensured food, water, and protection from predators; yet limit its activities to available space and human interference; thus, forcing the individuals to change their behaviour to extract its survival under the captive conditions. The behavioural modifications, however, are expected to remain within a range of the broad models set for the species in wild. The studies on behaviour of captive animals may help in understanding its basic wild behaviour and the possible change it can undergo under stress conditions.

By using the facility of semi-intensive breeding stock of hog deer at Changa Manga Wildlife Sanctuary, the present study was designed to examine the social behaviour, time budget and seasonal variation of hog deer. The study will help in understanding the behavioural aspects of the selected species in semiintensive conditions. The information collected thus can be used in development of management strategy for the wild population of the species, and also behavioural changes in the captivity bred stock and hence in the proper management to re-introduce into the natural habitat.

\section{Materials AND Methods}

\section{STUDY AREA}

The research was carried out at Wildlife Park Changa Manga forest $\left(31^{\circ} 08^{\prime} \mathrm{N}\right.$ and $\left.73^{\circ} 99^{\prime} \mathrm{E}\right)$ in Kasur District, Punjab, Pakistan. A total of 59 hog deers (adult males $=$ 29 , females $=24$, fawns $=6$ ) are maintained as breeding flock in an exclusive enclosure of about one hectare. However, 18 subjects (males 6: females 6: fawns 6) were utilized to carry out the objective outcome. One male nilgai (Boselaphustrago camelus) is also maintained in the enclosure. The enclosure has 28 trees of mulberry (Moris sp.) inter-spread with 10 trees of Populus sp. (safeeda). The herd was offered $250 \mathrm{~g} /$ day/ animal of chickpea, and $125 \mathrm{~g}$ / animal of jaggery (gur) on alternate days at about 08:00 h. Green fodder, as available in different seasons, was offered $5 \mathrm{~kg} /$ day/ animal at around 10:00-11:00 h.

\section{DATA COLLECTION}

Hog deer enclosure was visited by researchers to familiarize with the conditions of the enclosure, sex, and age variation in hog deer herd, and individual/ herd marking for identification. A suitable platform and hideout were developed in proximity of the enclosure, from where the activities of hog deer in the enclosure could be observed without disturbing the animal and keeping to the safety of the workers. Necessary ethical approval of the relevant wildlife administration was taken for conduct and to muster their possible support for the study. On each day, one male, one female and one fawn were selected and marked with different colors as well as body size, horn size, and mother guided response. 18 hog deer of different age and sex were maintained in enclosure fed with natural and artificial feed. The research animals were retained in 2-3 groups of randomly varying size and compositions at different times of the day and during the breeding season. Maximum effort was made to maintain the same animals for observation on different days and season; though the animals studied at different times were not the same.

The selected animals were observed for 30:00 h at 02:00 $\mathrm{h}$ interval for three consecutive days round the clock (24:00 h) across winter, spring, summer, monsoon and autumn season without disturbing the animals. During winter, observation in night-time was not possible due to dense fog. The subjects were observed for every 02:00 $\mathrm{h}$ interval. Time spent on different activities recorded by naked eyes and/or with binoculars, using focal animal sampling technique (Altmann 1974). General observations on group size, sex and age composition, and feeding on natural vegetation were also recorded during each visit.

The observations were made by a team of three workers, each following a specific animal (male, female or fawn). Figure 1 presents a summary of relative time spent that has been pooled together to represent time spent in percentages prior to ANOVA application on different activities by the fawn, adult female and adult male hog deer in all studied seasons. Time budget of behavioural activities such as walking (purposeless wandering in cage), running (faster than walking, particular in danger or running after the female, or male running after to fight with male), standing (still position), sitting (keeping head up), resting (sitting or lying keeping head on ground), sleeping (keeping head to ground with closed eyes), feeding (grazing on wild vegetation or forage provided; animal while feeding on artificial feed ration was ignored), rumination (chewing 
cud) and others (grooming, rubbing, scratching and licking, drinking, defecation, and licking salt) were recorded. Each activity was standardized before the start of study and fully shared between team members.

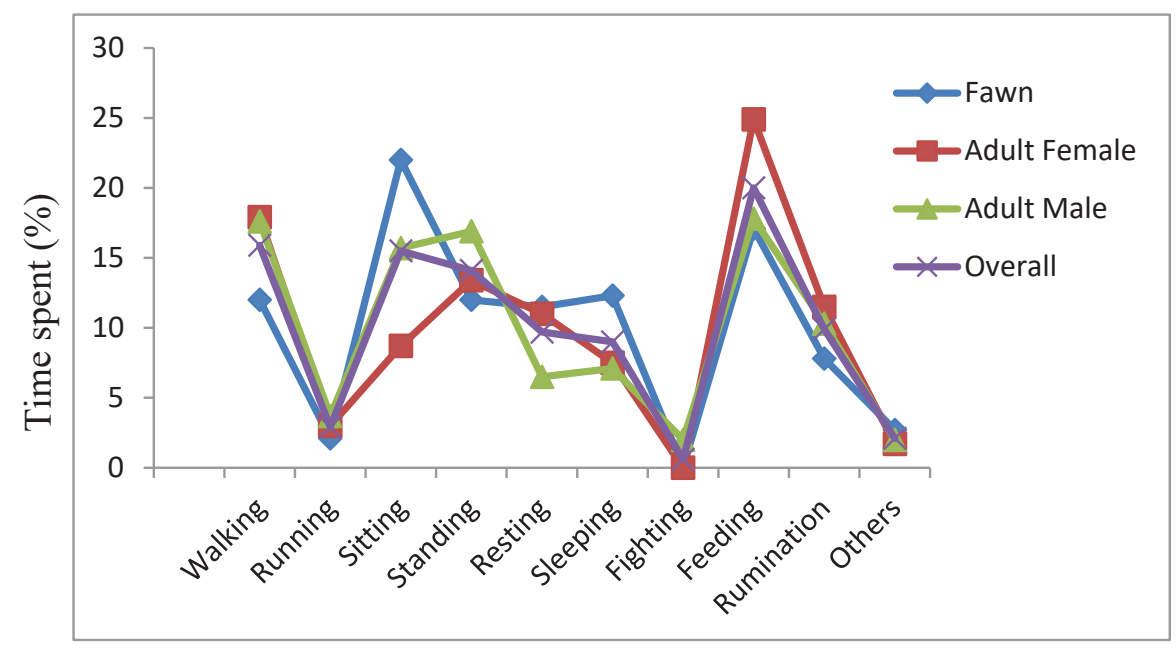

FIGURE 1. Average relative time spent on different activities by hog deer at Changa Manga enclosure

\section{ANALYSIS}

Total time spent of adult males, adult females and fawn's activities in different season were pooled and represented as relative time consumed (\% of total time consumed in study). Descriptive statistical constants were calculated and significance of difference in time budgeting and group behaviour was measured by ANOVA at 0.05 significance level (McDonald 2009).

\section{RESULTS}

\section{SOCIAL BEHAVIOUR}

In general, all individuals spent $20 \%$ time in feeding, $10 \%$ to ruminate, $9 \%$ in rest and $4 \%$ in sleep as shown in Figure 1. The results were significantly different in all behaviour activities $(\mathrm{F}=12.5, \mathrm{df}=1,9, \mathrm{P}<0.05)$. Fawns spent appreciably higher proportion of time sleeping $(13 \%)$ and less in feeding (17\%) followed by walking $(12.5 \%)$ compared to adults. As far as other activities concerned, fawns showed no appreciable difference from adults $(\mathrm{F}=0.0000001$, $\mathrm{df}=1,18, \mathrm{P}>0.05)$. Average adult males spent high proportion of time in sitting (males $=16 \%$, females $=9 \%$ ) and females in feeding (females $=25 \%$, males $=18 \%$ ) as well as for rest (females $=11 \%$, males $=6 \%)$. Overall, ANOVA suggests no significant difference between sex $(F=0.0000001$, df
$=1,18, \mathrm{P}>0.05)$ regarding activities of adult hog deer (Figure 1).

\section{SEASONAL VARIATIONS}

Herd spent relatively more time to walk $(19.6 \pm 5.9 \%)$, running $(6.00 \pm 2.8 \%)$, rest $(17.8 \pm 4.5 \%)$ and feeding $(26.4 \pm 6.2 \%)$ in winter (Figure 2). Higher proportion of time was devoted to rest in summer $(11.4 \pm 2.5 \%)$ and monsoon $(12.1 \pm 1.6 \%)$. Relatively, less time was utilized for walk in summer $(12.9 \pm 4.6 \%)$, sitting in monsoon $(12.5 \pm 4.7 \%)$ and rumination in winter $(4.1$ $\pm 4.7 \%)$. ANOVA suggests no significant difference $(\mathrm{F}=0.0000001, \mathrm{df}=4,45, \mathrm{P}>0.05)$ in activities of hog deer across seasons, as well as in activities of adult females $(\mathrm{F}=0.00000001, \mathrm{df}=4,45, \mathrm{P}>0.05)$ and in adult males $(\mathrm{F}=0.0000001, \mathrm{df}=4,45, \mathrm{P}>0.05)$ across seasons. Adult males devoted higher proportion of time in running. Adults spent comparatively less time in walking during summer and monsoon, sitting during spring and sleep during monsoon. Adult females spent higher proportion of time in walking, sitting and resting during winter, sleeping in autumn and feeding in spring. Fighting was recorded in monsoon and autumn among adult males only.

ANOVA also suggests no significant difference $(\mathrm{F}=0.0000001, \mathrm{df}=4,45, \mathrm{P}>0.05)$ in activities of fawns 
across seasons. Fawns spent relatively less time in walking during summer, sitting in autumn, resting in spring, autumn and relatively more proportion of time was spent on feeding in winter. Fighting was limited to fawn males in monsoon and autumn only.

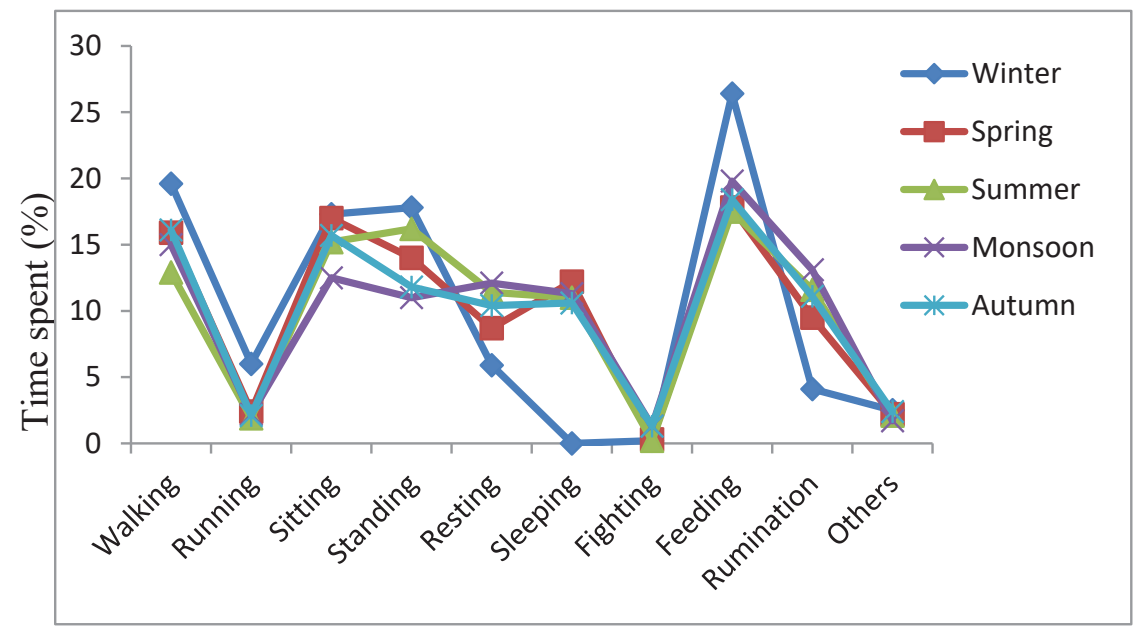

FIGURE 2. Average time spent on different activities during different seasons by hog deer in Changa Manga enclosure

\section{CIRCADIAN TIME BUDGET}

Figure 3 represents relative time consumption in various activities by hog deer in different hours of the day. Hog deer slept in mid night (22:00 to 02:00 h). Hog deer spent more time in walking at midnight and early morning (04:00 to 8:00 h). However, walking continued the rest of the day. Hog deer was more active at earlier parts of the day and resting activity was less in earlier hours (06:00 to 10:00 h). Hog deer spent more time sitting at mid days (particular in summer) and early hours of day standing. During standing, hog deer remained alert in head up posture and relied more on natural feeding at dawn $(04: 00$ to $8: 00 \mathrm{~h})$, midday $(10: 00$ to $15: 00 \mathrm{~h})$ and dusk (18:00 to 20:00 h). Time spent while rumination was more at midday (12:00 to 14:00 h) and night (22:00 to $04: 00 \mathrm{~h}$ ). On the other hand, adult male spent some time fighting during rutting season in early parts of the day (06:00 to 10:00 h).

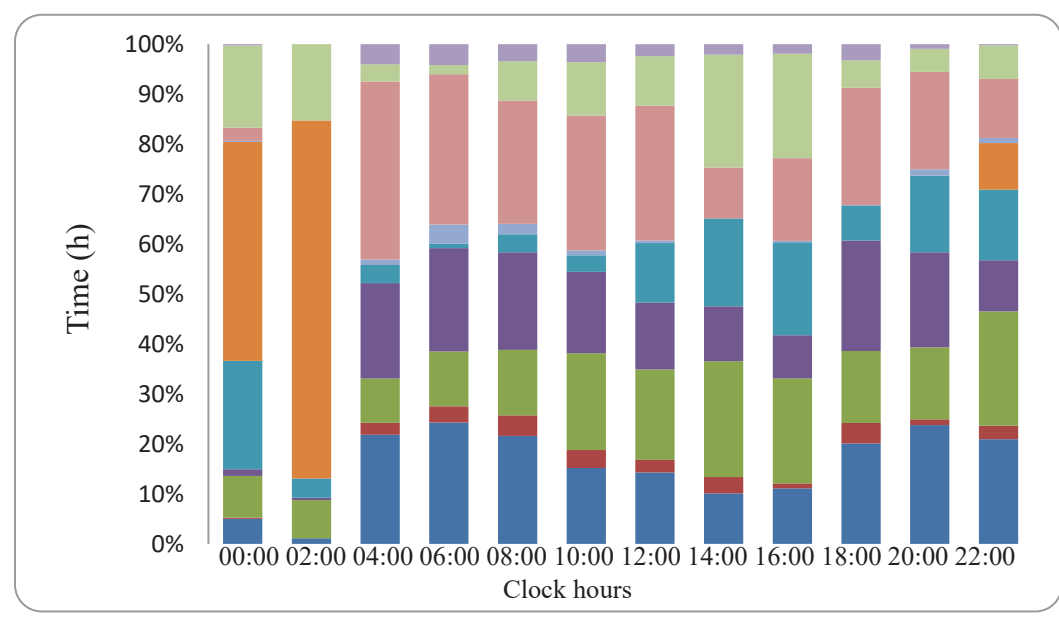

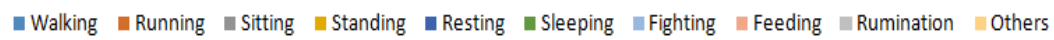

FIGURE 3. Relative time spent on different activities at different clock hours of the day by hog deer 
Average time consumption in various activities by fawns, adult female and adult male hog deer in different hours of day suggests non-significant difference in different activities between fawns, adult females, and males. Fawns spent more time resting and sitting in mid-day compared to adults. In early parts of day all animals were active, involved in feeding, movement and slept at mid-night.

\section{SEASONAL VARIATION IN DAILY ACTIVITIES}

Figure 4 represents percentage time consumption during a day in different activities of winter season. Time spent in walking and movements was more in early day (06:00 to $10: 00 \mathrm{~h})$ and night $(20: 00$ to $22: 00 \mathrm{~h})$. At mid-day $(12: 00$ to $14: 00 \mathrm{~h})$ and night $(12: 00$ to $02: 00$ $\mathrm{h}$ ), more time were spent on sitting and resting. Hog deer spent most of the daytime feeding. Maximum time spent for natural feeding was at dawn, dusk, and midday. Time spent for rumination was at mid night with less fighting in winter. Figure 5 represents percentage time consumption during a day in different activities in spring season. Time spent in walking and movements was more in early day. At afternoon and earlier night, more time were spent sitting and resting. Hog deer spent

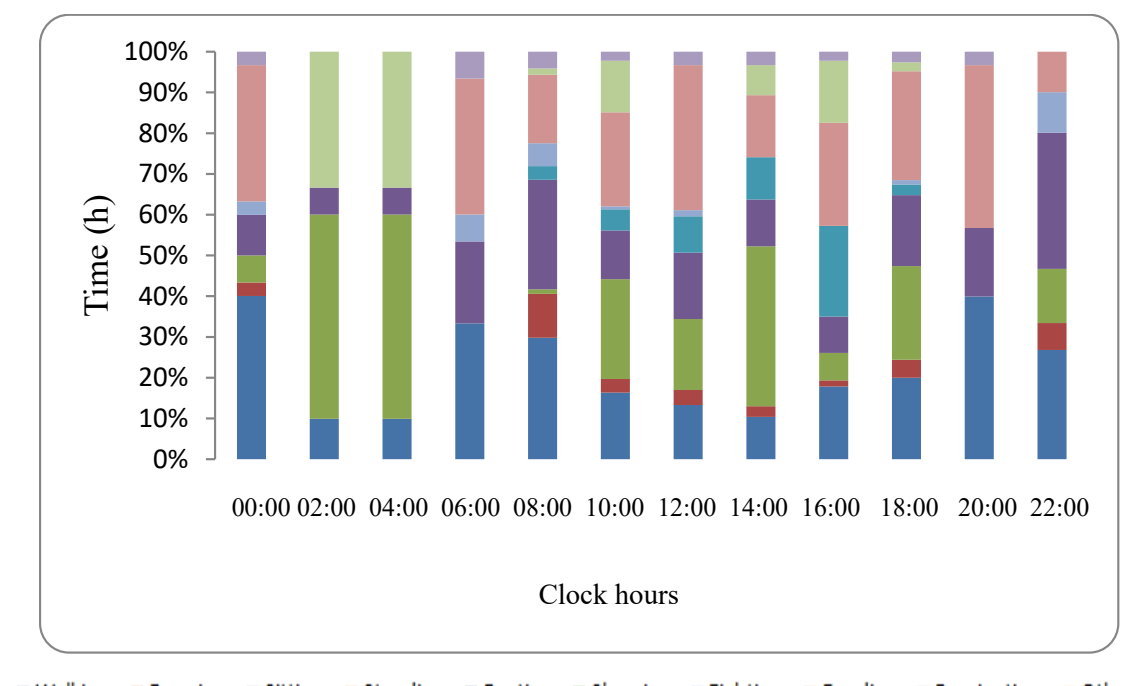

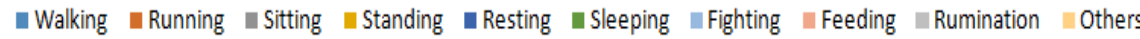

FIGURE 4. Relative time spent on different activities at different clock hours of the day by hog deer in winter

most of the daytime feeding. Maximum time spent while feeding was at mid-day and time spent while rumination was early night. However, percentage time consumption in various activities by hog deer in various hours of a day in summer and autumn were similar as observed in spring and monsoon. Hog deer spent early in the morning in movements and feeding. Hog deer spent most of time resting during hot afternoon in summer season. Figure 6 represents percentage time consumption during a day in different activities in monsoon and autumn, respectively. Hog deer spent earlier parts of day (04:00-10:00 h) more in movements and fighting. However, sleeping was observed at midnight along with sitting, resting and rumination at afternoon.

\section{DISCUSSION}

The presence of free moving hog deer in a 1-hectare enclosure in 2-3 groups with no antagonistic responses of individuals confirmed non-territoriality of species. The present results have no direct bearing on home range species due to confinement in small enclosure, each individual getting some $340 \mathrm{~m}^{2}$, and additional feeding ration at specific point.

Hog deer is a non-territorial animal with wide home range requirement (Odden \& Wegge 2007). Group size up to 20 has been reported for hog deer flock maintained at Chitwan Park (India), though majority remained isolated along with groups of females with juveniles were most common (Dhungel \& O'Gara 1991). 


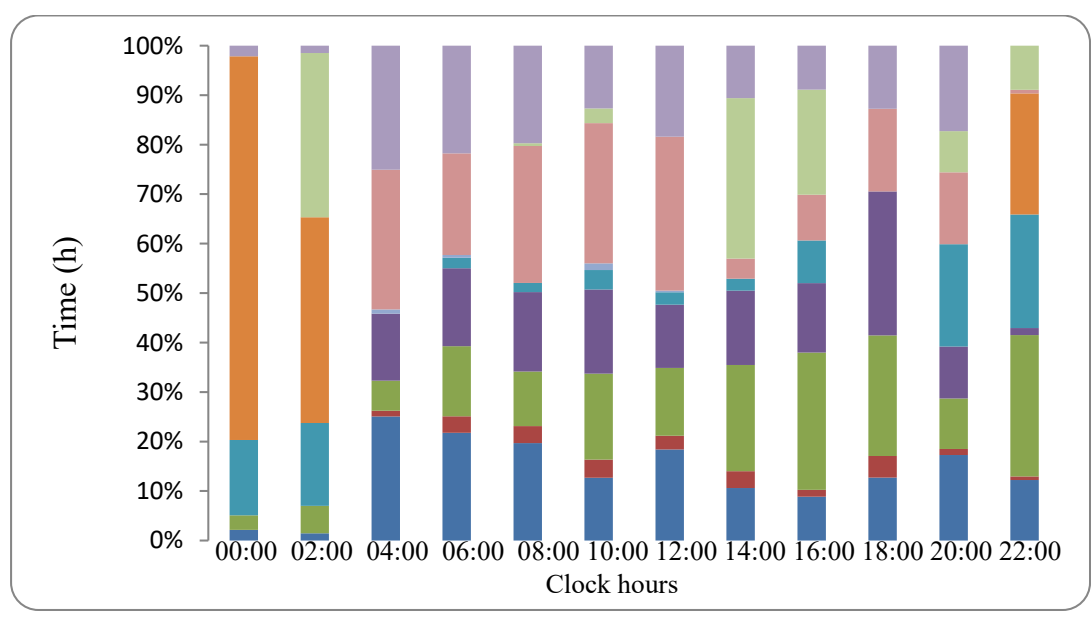

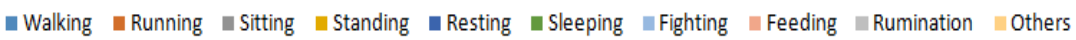

FIGURE 5. Relative time spent on different activities at different clock hours of the day by hog deer in spring

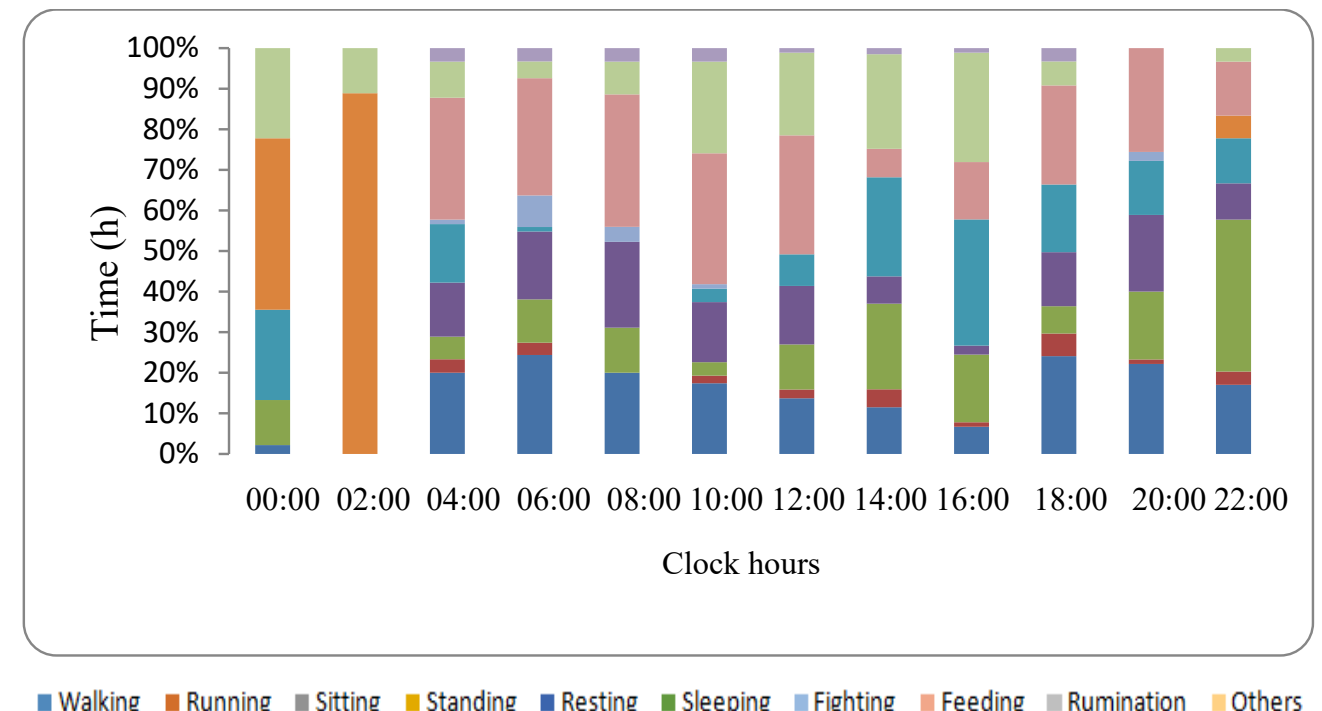

FIGURE 6. Relative time spent on different activities at different clock hours of the day by hog deer in monsoon

Bigger group size in Changa Manga enclosure was due to space shortage. This however suggests that hog deer does not maintain territoriality, as indicated by Odden and Wegge (2007) and can stay in smaller space. Home range of species in Chitwan Park has been recorded as 80 ha for males and 60 ha for females though overlapping was existing too (Dhungel \& O'Gara 1991; Miller 1975).
The current findings showed that hog deer in enclosure spent most time feeding and rest among all activities observed. Khan et al. (2012) reported hog deer preferred rest under enclosure conditions, which was consistent with present study. Dhungel and O'Gara (1991) also confirmed Chitwan park hog deer spent around $34 \%$ of average daily time running, walking and 
feeding. The flock under present enclosure conditions spent considerable proportion of time $(46 \%)$ in such activities which was in agreement to Dhungel and O'Gara. Khan et al. (2012) reported higher purposeless walk under congested zoo conditions; which might partially explain higher time allocation for such activity in present study. Disturbance caused due to human actions as well as enclosure conditions (in/out) has also affected the behaviour of hog deer. Fawns spent higher proportion of time rest, sleep, feed and walk compared to adults. No previous study is available on exploration of time consumed by fawns in these activities. Fawns spend more time resting as protective strategy to avoid walking out of protection. However, adult males spent higher proportion of time resting and females in feeding. Such a difference in activity pattern of two sexes along with age is hard to be explained without comparison in enclosure and wild conditions.

Hog deer did not go to sleep at early evening to midnight (18:00-24:00 h) during winter. This is probably a wild behaviour to protect animal during colder night. The logic needs further supportive data; yet the species live in dense tall grasses in riverine bella with no shelter where chill effect during night is strong. The species spend more time in walking, running, resting and feeding during winter which help in providing metabolic energy to fight winter cold. However, more time during summer and monsoon when harsh summer temperature requires cooling and safety from exertion.

Fighting between males was frequent in monsoon and autumn. Rutting period is July-October in India (Schaller 1967) and September-October in Burma (Yin 1967); which is associated with aggressive behaviour in males. The flock under enclosure conditions appears to follow its natural breeding cycle, when males go for rut and associated fighting.

The hog deer in enclosure showed somewhat similar to natural and habitual crepuscular feeding behaviour (grazing/browsing at dusk and dawn). Crepuscular feeding behaviour has been frequently reported for hog deer (Dhungel \& O'Gara 1991; Odden \& Wegge 2007; Schaller 1967; Tuboi \& Hussain 2016). This is despite the fact that hog deer under enclosure conditions was offered natural fodder and nutrition supplements in the morning for adequate nutrition supply, yet, flock maintains its wild behaviour. Rumination occurred at mid-day and late night followed by crepuscular feeding bouts at dusk and dawn. Animals were more active during early hours of day and such pattern has been indicated previously by Dhungel and
O'Gara (1991), suggesting species active percentage 41\% during the day and $29 \%$ at night.

\section{CONCLUSION}

Hog deer maintains wild behaviour and time budgeting even under congested conditions of enclosure with slight variation. Animal spends less time running and walking under enclosure condition due to possible captive stress. The hog deer (adults and fawns) showed tendency to rehabilitate in enclosure habitat that could make conservation programs successful. The current study provides guideline on how to manage the captive hog deer for conservation purpose.

\section{REFERENCES}

Altmann, J. 1974. Observational study of behavior: Sampling methods. Behaviour 49(3): 227-266.

Azam, M., Khan, S.A. \& Qamar, S. 2002. Distribution and population of hog deer in District Sanghar, Sindh. Zoological Survey Department of Pakistan 14 5-10.

Dhungel, S.K. \& O'Gara, B.W. 1991. Ecology of the hog deer in Royal Chitwan National Park, Nepal. Wildlife Monographs. pp. 3-40.

IUCN 2020. The IUCN Red List of Threatened Species. Version 2020-2. https://www.iucnredlist.org.

Khan, M.Z., Samreen, N., Ghalib, S.A., Zehra, A., Hussain, B., Tabbassum, F. \& Latif, T.A. 2012. Biology and behaviour study of Chinkara, Cheetal, Nilgai, Blackbuck and Hog Deer in captivity in Karachi zoo and safari park. International Journal of Biology and Biotechnology (Pakistan) 11(3): 341-349.

McDonald, J.H. 2009. Handbook of Biological Statistics. Baltimore, MD: Sparky House Publishing 2: 173-181.

Miller, R. 1975. Notes on the behaviour of hog deer in an enclosure. Natural History Bulletin-Siam Society 26: 105113.

Odden, M. \& Wegge, P. 2007. Predicting spacing behavior and mating systems of solitary cervids: A study of hog deer and Indian muntjac. Zoology 110(4): 261-270.

Schaller, G.B. 1967. The Deer and the Tiger. A Study of Wildlife in India. Chicago: University of Chicago Press.

Tuboi, C. \& Hussain, S.A. 2016. Factors affecting forage selection by the endangered Eld's deer and hog deer in the floating meadows of Barak-Chindwin Basin of North-east India. Mammalian Biology-Zeitschrift für Säugetierkunde 81(1): 53-60.

Williams, G.C. 2008. Adaptation \& Natural Selection: A Critique of Some Current Evolutionary Thought. Princeton: Princeton University Press.

Yin, T. 1967. Wild Animals of Burma. Rangoon: Rangoon Gazette Ltd. 11: 1-301. 
Zahid Farooq, Irfan Baboo* \& Sana Asad

Department of Zoology

Cholistan University of Veterinary and Animal Sciences

Bahawalpur

Pakistan

Muhammad Younas \& Muhammad Wajid

Department of Zoology

University of Okara, Okara

Pakistan

Khalid Javed Iqbal

Department of Zoology

The Islamia University Bahawalpur

Bahawalpur
Muhammad Shahbaz \& Muhammad Saleem Khan Department of Zoology

Women University of Azad Jammu and Kashmir Bagh

Muhammad Mazhar Munir

Department of Pharmacology and Toxicology

Cholistan University of Veterinary and

Animal Sciences, Bahawalpur

Pakistan

*Corresponding author; email: irfanbaboo@gmail.com

Received: 25 December 2019

Accepted: 18 February 2021 